\title{
ROOTING STIMULATION IN MUSCADINE GRAPE CUTTINGS
}

\author{
P.R.C. CASTRO; E. MELOTTO; F.C. SOARES \\ Departamento de Botanica-ESALQ/USP, C.P. 09 - CEP: 13418-900, Piracicaba, SP \\ I.R.S. PASSOS; C.V. POMMER \\ Sę̧ão de Viticultura-IAC, C.P. 28, CEP: 13001-970 - Campinas,SP
}

\begin{abstract}
ARSTRACT: The muscadine grape (Vitis rotundifolia Michx.) is native to Forida and has been cultivated for many years in U.S.A. It is harvested as single berries instead of in bunches and bas small leaves. The fruit skin is thicker than those of bunch-type grapes. One reason for its popularity is that the muscadine is seldom seriously affected by diseases or insects. The muscadine grape is not readily propagated by hardwood cuttings, therefore the present work was carried out to develop a method for commercial propagation of its cuttings, using treatments with growth regulators (auxins) and low temperature. The results showed that the rooting of both basal and middle shoots of muscadine grape is better than the rooting of terminal sections of the shoots. Cuttings treated with low temperature $\left(4^{\circ} \mathrm{C}\right)$ during 24 hours, or immersion of the cutting's bases in solutions of Exuberone 10 and $20 \mathrm{ml} . \mathrm{I}^{-1}$, promoted rooting of middle and basal cuttings, respectively. The growth of leaves in both basal and middle cuttings was superior in the treatment with low temperature.
\end{abstract}

Key Words: Vitis rotundifolia Michx., cutting, growth regulators

\section{ESTIMULAÇÃO DO ENRAIZAMENTO DE ESTACAS DE Vitis roturadifolia MICHX}

\begin{abstract}
RESUMO: A videira muscadínia, nativa da Flórida, têm-se distinguido pela produtividade, resistência a pragas e doenças e pela característica de desbastar-se facilmente na colheita, possibilitando sua comercialização em cestas, de forma semelhante ao morango. As dificuldades na propagação desse grupo de videira têm impedido sua disseminação na região tropical úmida, em áreas onde a exploração de outras videiras tem sido dificultada pela alta incidência de doenças. O objetivo desse trabalho foi estabelecer o sistema mais adequado de propagação vegetativa de Vitis rotundifolia Michx., utilizando estacas apicais, medianas e basais, tratamentos com auxina e com baixa temperatura. Verificou-se que 0 enraizamento de estacas basais e medianas da videira muscadinia foi mais eficiente do que 0 de estacas apicais. Tratamento das estacas com temperatura de $4^{\circ} \mathrm{C}$ por 24 horas, ou imersão das estacas em solução de Exuberone 10 e $20 \mathrm{ml} . \mathrm{I}^{-1}$, promoveram o enraizamento de estacas medianas e basais, respectivamente. $O$ desenvolvimento da parte aérea das estacas basais e medianas da videira mostrou-se superior no tratamento com baixa temperatura.
\end{abstract}

Descritores: Vitis rotundifolia Michx., estaquia, reguladores vegetais

\section{INTRODUCTION}

The muscadine grape is native to Florida where it has been cultivated for many years. This type of grape has smaller leaves and thicker fruit skin as compared to other grapes. In addition, it is harvested as single berries instead of in bunches which influences the way the fruits are commercialized. Muscadine grapes are sold in baskets, similar to strawberries and cherries. The production can also be destined to the industry where the fruits are processed into delicious jellie, juice or even wire. The flavor of muscadine grapes resembles those of 'Niagara', 'Isabel', and 'Concord'.

For the cultivation of muscadine grape there is no need for rigid control of either soil acidity or diseases. The amount of chemicals utilized in this crop is usually very low which makes it a very atractive alternative for an increasing number of consumers who demand more natural, chemical-free products.

In Brazil, the cultivation of Vitis vinifera and Vitis labrusca at the coast and humid tropical regions has been hampered by the high incidence of diseases. Thus, the option to introduce 
muscadine grape in these regions should be considered. It is also interesting to note that the season for muscadine grape in Brazil is March / April when the offer of other fruits in the market is considerably low.

The most difficult problem to overcome for the commercial production of muscadine grape is perhaps related to its propagation. Unlike other grapes, rooting of hardwood cuttings of this species is rather troublesome, requiring special conditions and techniques.

GOODE \& LANE (1983) have studied the vegetative propagation of muscadine grapes using indolebutyric acid (IBA). Up to July, $80 \%$ of the cuttings formed roots, while after this month only $49 \%$ presented roots. The quality of roots increased when cuttings harvested up to June were treated with IBA. According to GOODE et al. (1982), muscadine cuttings present better rooting ability in the beginning of the dormant period. These authors have also found that cuttings of larger diameter form more roots than thinner ones and that warming of the cuttings contributes for a better rooting.

SHARPE (1954) have induced rooting in muscadine grape cuttings under mist; he found that rooting was satisfactory when apical regions were growing fast. His results indicated that commercial propagation was possible when cuttings were taken from main shoots.

According to HARMON (1943), the response of cuttings to IBA varies considerably among cultivars. Cultivars usually respond to concentrations from 0.005 to $0.02 \%$ of this growth regulator, when cuttings are treated for 24 hours. The presence of a node in the base of the cuttings benefits rooting. This author has also detected that rooting of cuttings taken from either Vitis rotundifolia or Vitis davidi was not stimulated by IBA.

As a result of an extensive study on the rooting of muscadine cuttings, COWART \& SAVAGE (1944) concluded that chemical treatment of cuttings, among other treatments, does not favor rooting. The authors have tested the influence of the timing of harvest, substrate and different storage conditions on the rooting of cuttings. None of the methods or techniques tested proved to be useful for root induction in this species. On the other hand, WOODROOF (1935) found that various cultivars of muscadine grape could be vegetatively propagated at any season through layerage of old grapevines.
MULLINS \& RAJASEKARAN (1981) have concluded from their work that cuttings of muscadine grapes can form roots in 4 weeks by warming their bases at the temperature of $26^{\circ} \mathrm{C}$. The bases of the cuttings are kept in a warm compartment while the room is cooled at the temperature of $4^{\circ} \mathrm{C}$ to keep the buds dormant. After rooting, cuttings are transferred to the greenhouse.

The objective of this work was to determine an economically viable way to vegetatively propagate muscadine grapes in the State of São Paulo, Brazil.

\section{MATERIAL AND METHODS}

On August 29th, cuttings of muscadine grapevines (Vitis rotundifolia Michx. cv. Dixie) were taken from different regions of plants grown in Campinas, São Paulo, Brazil. Apical cuttings had diameter of $3 \pm 1 \mathrm{~mm}$, while cuttings of the middle and basal regions were $5 \pm 1$ and $8 \pm 1$ $\mathrm{mm}$ in diameter, respectively. Cuttings were placed in a humidified bag and brought to the laboratory to be treated as follows:

\begin{tabular}{lccc}
\hline & \multicolumn{2}{c}{ Cuttings } \\
\cline { 2 - 4 } Treatment & Apical & Middle & Basal \\
\hline Control & water & water & water \\
NAA $\left(\mathrm{mg} . \mathrm{l}^{-1}\right)$ & 20 & 60 & 90 \\
IBA $\left(\mathrm{mg} . \mathrm{I}^{-1}\right)$ & 20 & 200 & 2000 \\
Exuberone $\left(\mathrm{ml} . \mathrm{l}^{-1}\right)$ & 5 & 10 & 20 \\
Temperature $\left({ }^{\circ} \mathrm{C}\right)$ & 4 & 4 & 4 \\
\hline
\end{tabular}

The 3 lower centimeters of the cuttings were immersed in solutions of naphtalene acetic acid (NAA), IBA and Exuberone (IBA in solution) for 24 hours, in the dark. After washing the growth regulators off the cutting's bases in water, they were planted in sand, under field conditions.

For each type of cuttings, the nonparametric test of Kruskal-Wallis was performed in a completely randomized experiment. Each experiment had 5 treatments composed of 10 cuttings each and repeated 5 times.

On the 76th day after planting (DAP), the shoot development of the cuttings was analyzed. Scores that varied from 1 to 5 , were given to the cuttings. No sprouting for score 1 and abundant sprouting for score 5 . Values 2,3 and 4 represented increasing intermediate sprouting. On 
the same day, the percentage of cuttings which formed roots was also taken.

\section{RESULTS AND DISCUSSION}

TABLES 1, 2 and 3 present scores given to the shoot development of apical, middle and basal muscadine grape cuttings respectively, on the 76th day after planting (DAP). They also show the results of the Kruskal-Wallis test. As shown in TABLE 1 , there were no significant differences among treatments of apical cuttings. Low temperature and auxin treatments were not effective to promote either shoot (TABLE 1) or root development (Figure 1) in this type of cutting. This result agrees with that of COWARD \& SAVAGE (1944) who had no success with the induction of roots in muscadine grape cuttings. In a work with Hevea brasiliensis, Castro et al. (1984) have shown that similar to muscadine grapes, this specie cannot be propagated through cuttings taken from the apical region of the plant. On the other hand, rooting can be achieved when cuttings are from the plant basal region.

TABLE 1. Scores given to shoot development of apical muscadine grape cuttings at $\mathbf{7 6}$ days after planting (DAP). Each value represents the average of 10 cuttings. The Kruskal-Wallis test $(\mathrm{H})$ result is also given.

\begin{tabular}{llllll}
\hline Treatment & \multicolumn{5}{l}{ Replicates } \\
\hline Control & 1.0 & 1.0 & 1.0 & 1.0 & 1.0 \\
NAA 20 mg. $1^{-1}$ & 1.0 & 1.0 & 1.4 & 1.4 & 1.0 \\
IBA 20 mg. $1^{-1}$ & 1.0 & 1.0 & 1.5 & 1.4 & 1.0 \\
Exuberone 5ml..$^{-1}$ & 1.0 & 1.0 & 1.0 & 1.0 & 1.0 \\
Temperature $4^{\circ} \mathrm{C}$ & 1.6 & 1.0 & 1.0 & 1.3 & 1.3
\end{tabular}

$\mathrm{H}=3.99^{\mathrm{m}}$

mot significant

In TABLE 2 we notice that middle cuttings show some response to both growth regulators and low temperature in terms of shoot development, which is related to rooting of the cuttings. As shown in TABLE 4, there were differences at the levels of $0.5,1$ and $5 \%$ of probability among treatments. Low temperature $\left(4^{\circ} \mathrm{C}\right)$ and Exuberone were more efficient than the control in the promotion of shoot development.
The efficiency of Exuberone in improving rooting was also described for ornamental species (FERNANDES et al., 1973).

TABLE 2. Scores given to shoot development of middle muscadine grape cuttings at 76 DAP. Each value represents the average of 10 cuttings. The KruskalWallis test $(H)$ result is also given.

\begin{tabular}{lccccc}
\hline Treatment & \multicolumn{3}{c}{ Replicates } \\
\hline Control & 1.4 & 1.0 & 1.0 & 1.0 & 1.0 \\
NAA 200 mg. $1^{-1}$ & 1.0 & 1.1 & 1.0 & 1.0 & 1.0 \\
IBA 200 mg.1 $1^{-1}$ & 1.0 & 1.0 & 1.0 & 1.0 & 1.0 \\
Exuberone $10 \mathrm{ml} .1^{-1}$ & 2.0 & 2.7 & 1.7 & 1.8 & 2.1 \\
Temperature $4^{\circ} \mathrm{C}$ & 2.1 & 2.5 & 3.7 & 2.5 & 2.4 \\
\hline
\end{tabular}

$H=17.91 * *$

** significant at $1 \%$ probability

The results presented in TABLE 3 indicate that the shoot development of basal cuttings of muscadine grapes was superior in the low temperature treatment.

TABLE 3. Scores given to shoot development of basal muscadine grape cuttings at $\mathbf{7 6}$ DAP. Each value represents the average of 10 cuttings. The Kruskal-Wallis test $(H)$ result is also given.

\begin{tabular}{lccccc}
\hline Treatment & \multicolumn{5}{c}{ Replicates } \\
\hline Control & 2.5 & 4.5 & 3.0 & 3.5 & 1.0 \\
NAA 90 mg. $1^{-1}$ & 5.0 & 4.5 & 1.0 & 5.0 & 3.0 \\
IBA 2000 mg. $1^{-1}$ & 1.0 & 1.0 & 1.5 & 1.4 & 1.0 \\
Exuberone 20 $\mathrm{ml}^{-1} 4.5$ & 4.5 & 4.0 & 3.0 & 4.5 \\
Temperature $4^{\circ} \mathrm{C}$ & 5.0 & 4.5 & 5.0 & 4.5 & 5.0
\end{tabular}

$\mathrm{H}=12.75^{*}$

* significant at $5 \%$ probability

Treatments with NAA and Exuberone tended to be better than the control, however, the differences were not significant at $5 \%$ probability (TABLE 4). The treatment of the cuttings with $2000 \mathrm{mg} \cdot \mathrm{l}^{-1}$ IBA inhibited shoot development as compared to the control. Similar results were found by CASTRO et al.(1984) in their work with Hevea brasiliensis. 
TABLE 4. Kruskal-Wallis test for average scores given to shoot development of apical, middle and basal muscadine grape cuttings at 76 DAP. Treatments ( 1 to 5 ) are listed in decreasing order of score within each experiment. The D.M.S. values are also given.

\begin{tabular}{lllllllll}
\hline \multicolumn{9}{c}{ CUTTINGS } \\
\hline Apical & \multicolumn{3}{c}{ Middle } & & \multicolumn{3}{c}{ Basal } \\
\hline Treatment & ns Treat. $0.5 \%$ & $1 \%$ & $5 \%$ & Treat. & $0.5 \%$ & $1 \%$ & $5 \%$ \\
\hline 1.(Control) & (5) 22.1 & a & a & a & (5) 20.6 & a & a & a \\
2.(NAA) & (4) 18.9 & ab & ab & a & (2) 15.5 & ab & ab ab \\
3.(IBA) & (1) 8.6 & b & b & b & (4) 14.2 & ab & ab ab \\
4.(Exuber.) & (2) 8.4 & b & b & b & (1) 10.2 & ab & ab bc \\
5.(4 $\left.{ }^{\circ} \mathrm{C}\right)$ & (3) 7.0 & b & b & b & (3) 4.0 & b & b & c
\end{tabular}

Obs: Averages followed by the same letter within the same column do not differ by the KruskalWallis test at the given probability.

Figure 1 shows the percentage of rooting in the 3 cutting classes treated with auxin at different concentrations and low temperature. From these results it is clear that the position of the plant from which cuttings are taken has a direct effect on rooting. Thicker cuttings, from the base of the plant, show the best results followed by middle and apical cuttings. These findings are corroborated by the work done by GOODE et al. (1982).

Treatment of the cuttings with IBA at

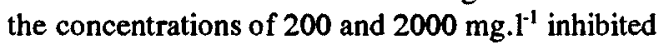
rooting (Figure 1). HARMON (1943) has also observed that exogenous IBA was not effective in inducing rooting in muscadine grape cuttings. The observation that basal cuttings form more roots than both middle and apical ones could be explained by the basipetal transport of endogenous auxin which would increase the concentration of this hormone in the basal region. High concentrations of endogenous auxin would in turn promote adventicious root formation (GASPAR \& HOFINGER, 1988). Auxin, either direct or indirectly, triggers the formation of adventicious roots in cuttings since it is required for the iniciation of the root primordia, presumably as early as the time of the induction of cellular division competence of the mother cells (HAISSIG, 1970).

Sci. agric., Piracicaba, 51(3):436-440, set./dez. 1994

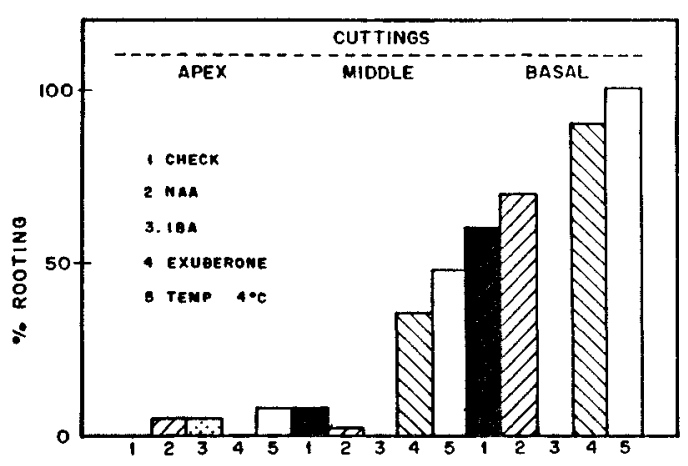

Figure 1. Percentage of rooting in apical, middle and basal muscadine grape cuttings, at 76 DAP, upon low temperature and auxin treatments in relation to the control.

\section{CONCLUSIONS}

1) In Vitis rotundifolia, the competence for rooting was higher in basal cuttings (hardwood), followed by middle and apical (herbaceous) cuttings.

2) Both low temperature $\left(4^{\circ} \mathrm{C}\right)$ and $10 \mathrm{ml} \cdot 1^{-1}$ Exuberone treatments were more efficient in inducing rooting of middle cuttings.

3) Both low temperature $\left(4^{\circ} \mathrm{C}\right)$ and $20 \mathrm{ml} . \mathrm{l}^{-1}$ Exuberone promoted rooting of basal cuttings.

4) Shoot development of both basal and middle cuttings was more pronounced in the low temperature $\left(4^{\circ} \mathrm{C}\right)$ treatment as compared to auxin treatments.

\section{REFERENCES}

CASTRO, P.R.C.; FACHINELLO, J.C.; FAQUIM, V.; RAMALHO, J.F.G.P.; BACCHI, O.O.S. Estimulaçāo do enraizamento de estacas de seringueira (Hevea brasiliensis Muell. Arg.). Anais da Escola Superior de Agricultura "Luiz de Queiroz", Piracicaba, v. 41, p. 349-357, 1984.

COWART, F.D.; SAVAGE, E.F. The effect of various treatments and methods of handling upon rooting of muscadine grape cuttings. Proceedings of the American Society for Horticultural Sciences, Geneva, v.44, p.312-314, 1944. 
FERNANDES, P.D.; CASTRO, P.R.C.; KRONKA, S.N.; AGUIAR, I.B. Ação de um regulador de crescimento no enraizamento de estacas de quatro plantas ornamentais. Anais da Escola Superior de Agricultura "Luiz de Queiroz", Piracicaba, v.30, p.217-226, 1973.

GASPAR, T.; HOFINGER, M. Auxin metabolism during adventitious rooting. In: DAVIS, T.D.; HAISSIG, B.E.; SANKLA, N. (eds.) Adventitious root formation in cuttings. Advances in Plant Sciences Series, v.2, Dioscorides Press, Portland, p.117-131, 1988.

GOODE, D.Z.; LANE, R.P. Rooting leafy muscadine grape cuttings. HortScience, Alexandria, v.18, p.944-946, 1983.

GOODE, D.K.; KREWER, G.W.; LANE, R.P.; DANIELL, J.W.; COUVILLON, G.A. Rooting studies of dormant muscadine grape cuttings. HortScience, Alexandria, v.17, p.644-645, 1982.

HAISSIG, B.E. Influence of indole-3-acetic acid on adventitious root primordia of brittle willow. Planta, Berlin, v.95, p.27-35, 1970.
HARMON, F.N. Influence of indolebutyric acid on the rooting of grape cuttings. Proceedings of the American Society for Horticultural Sciences, Geneva, v.42, p.383-388, 1943.

MULLINS, M.G.; RAJASEKARAN, K. Fruiting cuttings: revised method for producing test plants of grapevine cultivars. American Journal of Enology and Viticulture, Betesda, v.32, p.35-40, 1981.

SHARPE, R.H. Rooting of muscadine grapes under mist. Proceedings of the American Society for Horticultural Sciences, Geneva, v.63, p.88-90, 1954.

WOODROOF, J.G. Developments in growing muscadine grapes in the south. Proceedings of the American Society for Horticultural Sciences, Geneva, v.33, p.447-449, 1935.

Recebido para publicação em 11.03.94 Aceito para publicação em 30.06 .94 